\title{
Generation of genetically-engineered animals using engineered endonucleases
}

\author{
Jong Geol Lee ${ }^{1,2} \cdot$ Young Hoon Sung ${ }^{1,3} \cdot$ In-Jeoung Baek ${ }^{1,3}$ (B)
}

Received: 18 February 2018/ Accepted: 1 May 2018/Published online: 17 May 2018

(C) The Author(s) 2018

\begin{abstract}
The key to successful drug discovery and development is to find the most suitable animal model of human diseases for the preclinical studies. The recent emergence of engineered endonucleases is allowing for efficient and precise genome editing, which can be used to develop potentially useful animal models for human diseases. In particular, zinc finger nucleases, transcription activator-like effector nucleases, and the clustered regularly interspaced short palindromic repeat systems are revolutionizing the generation of diverse genetically-engineered experimental animals including mice, rats, rabbits, dogs, pigs, and even non-human primates that are commonly used for preclinical studies of the drug discovery. Here, we describe recent advances in engineered endonucleases and their application in various laboratory animals. We also discuss the importance of genome editing in animal models for more closely mimicking human diseases.
\end{abstract}

Keywords Genome editing · Engineered endonuclease · ZFN · TALEN · CRISPR

Young Hoon Sung

yhsung@amc.seoul.kr

$\triangle$ In-Jeoung Baek

ijbaek@amc.seoul.kr

1 ConveRgence mEDIcine research cenTer (CREDIT), Asan Institute for Life Sciences, Asan Medical Center, Seoul, Republic of Korea

2 College of Veterinary Medicine, Chungbuk National University, Cheongju, Republic of Korea

3 Department of Convergence Medicine, ConveRgence mEDIcine research cenTer (CREDIT), Asan Institute for Life Sciences, Asan Medical Center, University of Ulsan College of Medicine, Seoul, Republic of Korea

\section{Introduction}

In the fields of drug discovery and development, in vivo experiments using appropriate animal models are indispensable for successful clinical translation, which can lead to the development of preventatives or treatments for human diseases. Additionally, studies adopting geneticallyengineered animals can also provide us the important clues for the underlying mechanisms that make us to understand the pathology of the disease.

Genome editing refers to the manipulation of specific gene loci with engineered endonucleases in cultured cells or living organisms to modify the genome (Cong et al. 2013; Gaj et al. 2013; Shao et al. 2016). The key step in genome editing is the induction of site-specific doublestrand breaks (DSBs) by engineered endonucleases that are subsequently corrected by one of two competing DNA repair pathways, non-homologous end-joining (NHEJ) and homology-directed repair (HDR) (Sander and Joung 2014): NHEJ is characterized by the direct ligation of two DNA DSB ends frequently introducing unpredictable patterns of insertions and/or deletions (in-dels) leading to gene disruption or "knockout" through frameshift mutation, while HDR is an error-free mechanism that can be used to induce sequence-defined mutations or to insert a desired sequence at the targeted locus (Ceccaldi et al. 2016; Li et al. 2017).

Recent advances in genome editing technologies reflect the rapid development of engineered endonucleases including zinc finger nucleases (ZFNs), transcription activator-like effector nucleases (TALENs), and clustered regularly interspaced short palindromic repeat (CRISPR) systems, and now we can rapidly generate disease-associated animal models for a wide range of species (Dow 2015; Wang and Qi 2016). The engineered endonuclease-mediated genome editing approach has been established in 
many species, particularly in laboratory animals such as mice (Carbery et al. 2010; Meyer et al. 2010; Sung et al. 2013; Wang et al. 2013), rats (Geurts et al. 2009; Tesson et al. 2011; Li et al. 2013a, b), rabbits (Flisikowska et al. 2011; Song et al. 2013; Yang et al. 2014), dogs (Zou et al. 2015), pigs (Whyte et al. 2011; Carlson et al. 2012; Hai et al. 2014), and even non-human primates (Sato et al. 2016; Niu et al. 2014; Liu et al. 2014). The expanded application of genome editing to generate transgenic animals beyond mice will be advantageous in biomedical research because of its potential to accelerate the development of new therapeutic strategies (Wang and Qi 2016).

Here, we summarize the practical applications of three major engineered endonucleases-ZFN, TALEN, and CRISPR - that have been successfully used to edit genomes, with an emphasis on those of laboratory animals. In addition, we describe their advantages, disadvantages, and recent advances in genome editing. We hope to inform readers which tools can be useful options for desired tasks in desired laboratory animals.

\section{Engineered endonucleases frequently used in generating genetically-engineered animals}

An endonuclease must exhibit two characteristics to be useful for genome editing: (1) specific recognition of target sequences and (2) sufficient adaptability to target user-defined sequences (Urnov et al. 2010). The four genomeediting tools-ZFN, TALEN, and CRISPR/Cas including Cas9 and Cpf1-all satisfy these specifications, but there are some differences among them in terms of origin, structure, and action mechanism.

\section{Zinc finger nuclease}

ZFN was first devised by Kim et al. in 1996 and was initially applied to the fruit fly for genome editing (Bibikova et al. 2002, 2003).

$\mathrm{ZFN}$ is composed of the DNA binding domain of zinc finger protein (ZFP) linked with the endonuclease domain of the FokI restriction enzyme. ZFN acts through DNA/ protein recognition, as the ZFP region contains 3-6 tandem fingers, each of which recognize 3 bp of DNA (Miller et al. 1985; Wolfe et al. 2000). As FokI must dimerize to cleave DNA and this interaction is weak (Vanamee et al. 2001), ZFN should be designed as a pair, one on the forward strand and the other on the reverse strand, to permit the correct orientation and appropriate spacing for FokI dimerization. Once ZFP regions bind to either side of the target site (the total of both sides, 18-36 bp), the FokI domains dimerize and cleave the target DNA sequence
(Urnov et al. 2010), generating a site-specific DSB that is subsequently repaired via the HDR or NHEJ pathway.

\section{Talen}

TAL effector (TALE) represents the largest family of type III effector proteins from Xanthomonas spp., a group of gram-negative bacterial plant pathogens that was first discovered in 1989 (Bonas et al. 1989). Its capability to bind to DNA was first described in plants in 2007 (Romer et al. 2007; Kay et al. 2007), and the codes for recognizing the target DNA by TALE proteins were decrypted in 2009 (Moscou and Bogdanove 2009; Miller et al. 2011).

The DNA binding domain of naturally occurring TALE consists of 10-30 tandem repeats of the 34-amino acid module, which is highly conserved except for two hypervariable amino acid residues at positions 12 and 13, referred to as repeat-variable di-residue (RVD). The first base of the target recognized by an N-terminus region of TALE is generally specific for thymine, and the remaining bases are sequentially bound to RVD, in the manner where one type of RVD preferentially recognizes a specific nucleotide. Like ZFN, TALEN is generated by fusing the FokI endonuclease element to the engineered TALEbinding domain, and binds to the target sequence as dimers: each monomer binds to a "half-site" in the target and the FokI endonuclease domains dimerize to generate a DSB in the spacer sequence between the two half-sites.

\section{CRISPR/Cas9}

The CRISPR/CRISPR-associated protein (Cas) system was first observed in prokaryotes that mediate a bacterial adaptive immune defense against viruses or invading nucleic acids in 2007 (Barrangou et al. 2007). It was revealed in 2012 that mature dual RNA (crRNA:tracrRNA), following co-processing of tracrRNA and precrRNA by RNaseIII, is sufficient for Cas9-catalyzed DNA cleavage in Streptococcus pyogenes (Jinek et al. 2012), and subsequently, first evidences of genome editing using the CRISPR/Cas9 system were reported in mouse and human cells in 2013 (Cong et al. 2013; Mali et al. 2013b).

The CRISPR/Cas system is characterized by incorporating fragments of invading nucleic acid as spacers into a host genome and in the case of later infection, using them as templates to generate small RNA molecules (crRNA) that are combined with Cas proteins into an effector complex to silence foreign nucleic acids (Makarova et al. 2011). According to the latest classification based on the configuration of their effector modules, the diverse CRISPR-Cas systems can be divided into two classes: (1) 
class 1 CRISPR systems, which utilize several Cas proteins and crRNA to form an effector complex that includes type I and type III CRISPR systems, and (2) class 2 CRISPR systems, which employ a large single-component Cas protein in conjunction with crRNAs to mediate interference. In particular, type II CRISPR systems only require Cas 9 protein as an effector for DNA interference (Makarova et al. 2015).

In the CRISPR/Cas9 system, single guide RNA (sgRNA or gRNA) that is engineered as a complex of CRISPR RNA (crRNA) and trans-activating crRNA (tracrRNA) brings the endonuclease complex into the specific target site on the genome and then recruits Cas9 protein for precise DNA cleavage. sgRNA-guided target selection in the CRISPR/ Cas system, particularly Cas9 from $S$. pyongenes, requires a G-rich (NGG) protospacer adjacent motif (PAM) sequence at the $3^{\prime}$-end of the target site, which determines Cas 9 binding specificity to its target region. Once bound to the target sequence followed by PAM, Cas9 generates DSB 3-4 nucleotides upstream of the PAM site (Mali et al. 2013b). Table 1 summarizes the characteristics of $\mathrm{ZFN}$, TALEN, and CRISPR/Cas9 in genome editing.

\section{CRISPR/Cpf1}

Among class 2 CRISPR systems, a new type V CRISPRCas endonuclease, Cpf1 was first identified in Francisella and later in other bacteria Prevotella (CRISPR from Prevotella and Francisella 1) (Schunder et al. 2013; Vestergaard et al. 2014; Makarova et al. 2015). The CRISPR/
Cpf1 system was first applied as a genome editing tool in human cells in 2016, and it has three main distinct features from Cas9 (Zetsche et al. 2015): (1) tracrRNA is not required and thus the crRNA of Cpf1 is notably shorter than the sgRNA of Cas9. (2) sgRNA-Cpf1 complexes target DNA to produce DSB distal to a $5^{\prime}$-end T-rich PAM sequence, in contrast to Cas9, which produces DSB proximal to the $3^{\prime}$-end G-rich PAM site. (3) Cpf1 produces staggered DSB with a 4 or 5-nucleotide $5^{\prime}$-overhang (sticky end cut), whereas Cas9 cuts both strands in a DNA molecule at the same position (blunt end cut). Table 2 summarizes and compares the characteristics of Cas9 and Cpf1.

\section{Specificity of engineered endonuclease}

The most important hurdle to surmount in engineered endonuclease-mediated genome editing is its specificity and the off-target issue; the higher the specificity of the engineered endonucleases, the lower their off-target cleavage and hence their toxicity.

In ZFNs, the efficacy is largely dependent on the specificity of ZFPs. One way of increasing its specificity is to assemble the ZFP with an increased number of zinc finger modules to create a longer DNA recognition site, but this is not always sufficient. Another complementary approach is to design ZFN in a way such that the dimerization of the FokI cleavage domain occurs in the formation of a heterodimer rather than a homodimer, which will actively cleave only at specific heterodimer binding sites rather than at the homodimer or unintended binding sites

Table 1 Comparison of three engineered nucleases-ZFN, TALEN, and CRISPR/Cas9

\begin{tabular}{|c|c|c|c|}
\hline & ZFN & TALEN & CRISPR/Cas9 \\
\hline Backbone origin & $\begin{array}{l}\text { Highly prevalent in } \\
\text { eukaryotes }\end{array}$ & Bacteria (Xanthomonas spp.) & Bacteria (S. pyogenes) \\
\hline $\begin{array}{l}\text { Specificity } \\
\text { module }\end{array}$ & ZFP & TALE & sgRNA (crRNA + tracrRNA complex) \\
\hline $\begin{array}{r}\text { Cleavage } \\
\text { module }\end{array}$ & FokI & FokI & Cas9 \\
\hline Target site & $\begin{array}{l}18-36 \text { bp ( } 3 \text { nt per zinc } \\
\text { finger module) }\end{array}$ & $\begin{array}{l}\text { 30-40 bp ( } 1 \text { nt per RVD; TALE } \\
\text { binding sites should start with a } \\
\text { T) }\end{array}$ & $\begin{array}{l}20 \text { bp + PAM (NGG) sequence (Cas9 binding sites } \\
\text { should end with G-rich PAM) }\end{array}$ \\
\hline $\begin{array}{l}\text { Working } \\
\text { mechanism }\end{array}$ & $\begin{array}{l}\text { DNA/protein recognition, } \\
\text { DSB, and its repair } \\
\text { pathway }\end{array}$ & $\begin{array}{l}\text { DNA/protein recognition, DSB, } \\
\text { and its repair pathway }\end{array}$ & DNA/RNA recognition, DSB, and its repair pathway \\
\hline $\begin{array}{l}\text { Reprogramming } \\
\text { efficiency }\end{array}$ & Relatively low & Relatively low & $\begin{array}{l}\text { High (easier to design, faster to synthesize, and cost- } \\
\text { effective; furthermore, multiplex genome editing is } \\
\text { available) }\end{array}$ \\
\hline
\end{tabular}

$Z F N$ zinc finger nuclease, $Z F P$ zinc finger protein, TALE transcription activator-like effector, TALEN TALE nuclease, $R V D$ repeat-variable diresidue, CRISPR clustered regularly interspaced short palindromic repeat, Cas 9 CRISPR-associated enzyme 9, sgRNA single guide RNA, crRNA CRISPR RNA, tracrRNA trans-activating crRNA, PAM protospacer adjacent motif 
Table 2 Comparison of the characteristics of CRISPR/Cas9 and Cpf1

\begin{tabular}{|c|c|c|}
\hline & CRISPR/Cas9 & CRISPR/Cpf1 \\
\hline Backbone origin & Streptococcus pyogenes (SpCas 9$)$ & $\begin{array}{l}\text { Francisella novicida (FnCpf1), } \\
\text { Acidaminococcus sp. BV3L6 (AsCpf1), } \\
\text { Lachnospiraceae bacterium (LbCpf1) }\end{array}$ \\
\hline Structure of $\operatorname{sgRNA}$ & crRNA + tracrRNA & crRNA \\
\hline Nuclease domain & RuvC-like $+\mathrm{HNH}$ & RuvC-like \\
\hline PAM site & G-rich $\left(5^{\prime}-\mathrm{NGG}\right)$ & T-rich $\left(3^{\prime}-\mathrm{NTT}\right)$ \\
\hline Cutting mechanism & $\begin{array}{l}\text { Blunt cut } 3 \text { nt upstream of the PAM } \\
\text { (close to PAM) }\end{array}$ & $\begin{array}{l}\text { Staggered cut (with } 4-5 \text { nt overhang) } 17 \text { nt downstream of the PAM } \\
\text { (far from PAM) }\end{array}$ \\
\hline
\end{tabular}

CRISPR clustered regularly interspaced short palindromic repeat, Cas9 CRISPR-associated enzyme 9, sgRNA single guide RNA, crRNA CRISPR RNA, tracrRNA trans-activating crRNA, PAM protospacer adjacent motif

(obligate heterodimerization) (Miller et al. 2007; Szczepek et al. 2007). The combination of both approaches has been successful with high specificity in zebrafish embryos (Doyon et al. 2008), rat embryos (Geurts et al. 2009; Mashimo et al. 2010), and mammalian cells (Urnov et al. 2005; Lombardo et al. 2007; Perez et al. 2008; Hockemeyer et al. 2009), and there were also some improvements in the obligate heterodimerization strategy for ZFNs; for example, to abolish non-specific protein binding to the DNA backbone via amino acid substitutions (Ramalingam et al. 2011). These strategies are also beneficial for enhancing the specificity of TALENs (Huang et al. 2011; Hockemeyer et al. 2011; Cade et al. 2012).

The off-target issue is also the biggest concern in the CRISPR/Cas9 system (Fu et al. 2013; Hsu et al. 2013; Mali et al. 2013a; Pattanayak et al. 2013) and various efforts have been made to improve its specificity. Two methods that use distinct types of Cas9 pairs have been developed to reduce off-target effects in the CRISPR/Cas9 system: (1) A mutant version of Cas9 "nickase," in which one of either the Cas9 endonuclease domain histidine-asparagine-histidine (HNH) or RNase H-like fold (RuvC) is inactivated, can only introduce single-strand DNA breaks rather than DSB. Pairing the two nickase with their sgRNAs, allows a DSB with a $5^{\prime}$-overhang to be introduced at the target site, while single-strand nick at the off-target site would be fixed (Ran et al. 2013). (2) Another strategy to reduce off-target effects is to use of a pair of proteins, in which catalytically dead Cas9 (dCas9) is fused with the FokI domain. When the two FokI-dCas9 pairs are guided by two sgRNAs and subsequently positioned on both directions of the DNA strands, FokI endonuclease domains dimerize to generate a DSB in the on-target site (Tsai et al. 2014; Guilinger et al. 2014). The applications of the two above methods show drastically increased on-target specificity with reduced unexpected mutations in human cells, but it remains to be elucidated whether they work in vivo. Of course, it is always necessary to backcross mutant lines with multiple generations to remove any off-target mutations and/or verify the phenotypes with more than two independent lines.

\section{Genome editing using engineered endonucleases in laboratory animals}

Numerous model organisms have been developed and are now available to researchers, and mammalian models are now extensively used for studying basic biology and pathophysiology of human diseases and the development of novel therapeutics (von Horsten et al. 2003; Golding et al. 2006; Yang et al. 2008; Gilley et al. 2011; Hauschild et al. 2011; Zschemisch et al. 2012; Chan 2013). Studies that describe the first applications of ZFN, TALEN, and CRISPR in laboratory animals are summarized in Fig. 1.

\section{Mouse}

The mouse is the best-known and has been the most widely used mammalian model over the past century, particularly in the field of drug discovery and development, because therapeutic agents can be tested using mice in expeditious, cost-effective, and ethical manners. In genome engineering, it is an ideal animal in many aspects: (1) relatively low cost to maintain, (2) the short life-span beneficial to breed enough animals quickly and also suitable for the genetic studies, (3) it can develop various human-like diseases with wild-type and genetically-engineered animals, (4) $99 \%$ of its genes are shared with humans (Boguski 2002), and (5) many genetic resources have been developed and are now publicly available (Paigen 1995; Eppig 2017).

In the past, traditional genome editing in mice was only dependent on the HDR technique in embryonic stem (ES) 
Fig. 1 The timeline for the first applications of engineered nuclease technologies in laboratory animals. The time points when studies that describe the first applications of zinc finger nuclease (ZFN), transcription activator-like effector nuclease (TALEN), and clustered regularly interspaced short palindromic repeat (CRISPR) system including CRISPR-associated enzyme 9 (Cas9) and CRISPR from Prevotella and Francisella 1 (Cpf1) for genome editing in various laboratory animals were published are marked with colored circles (ZFN, yellow; TALEN, green; Cas9, blue; Cpf1, red)

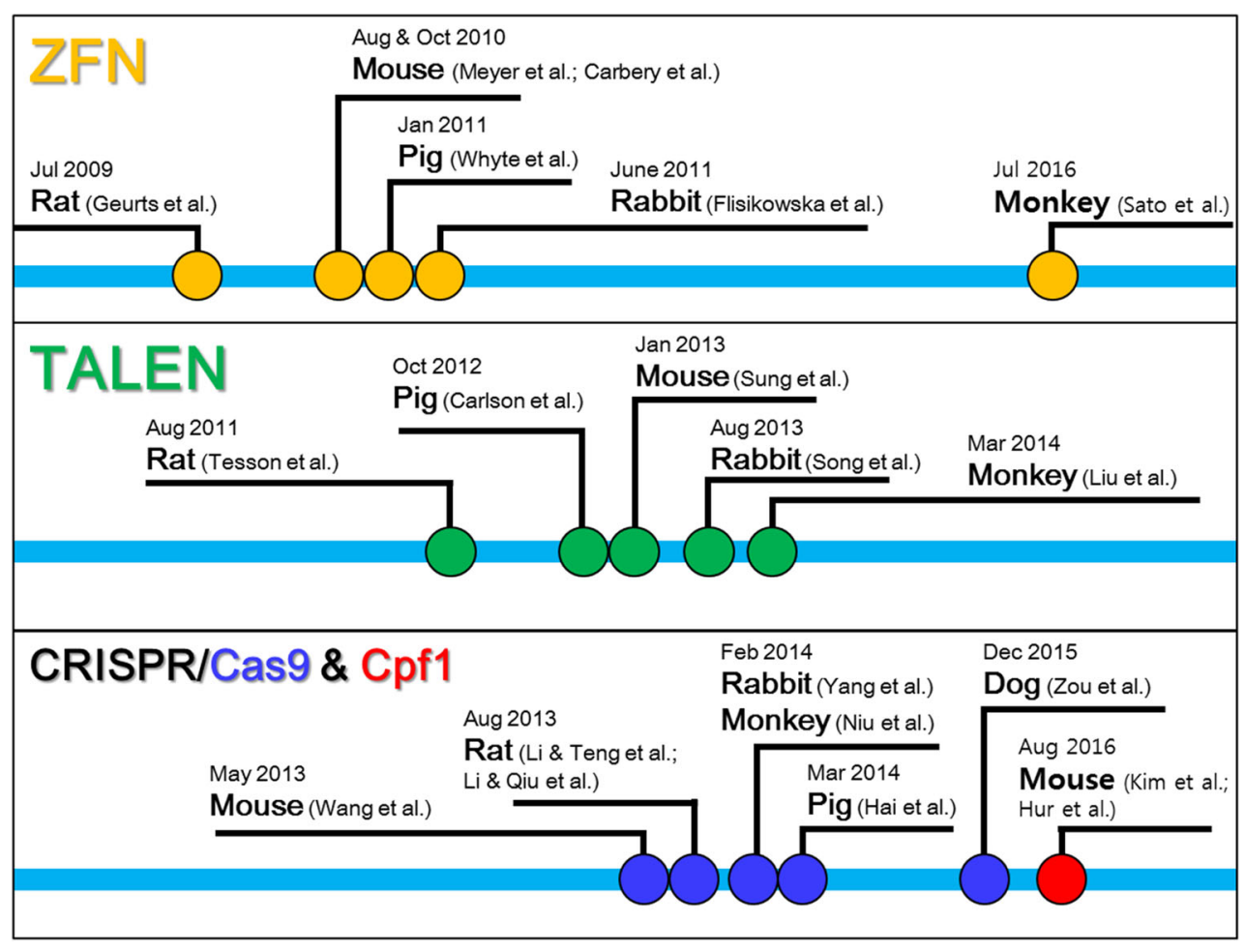

cells (Capecchi 1989). However, this strategy is characterized by multiple complicated steps: maintenance of ES cells in an undifferentiated state, construction of the targeting vector that should be electroporated into ES cells, positive and negative selections to enrich homologous recombinant ES cells, cloning and screening, expansion of correctly targeted ES cell clones, and the production of chimeric mice with germline transmission abilities. This method requires an enormous amount of time- and effortconsuming work, with no guarantee of success in every step.

Engineered endonuclease dramatically simplified the complicated processes for generating genetically-engineered mice (GEM), and was selected by Nature Methods as the "Method of the Year 2011" (2012). After the initial observation that genome editing using ZFN became applicable in the fruit fly (Bibikova et al. 2002, 2003), ZFN-based genome editing has been applied to both in vitro and in vivo models of various species, including $\mathrm{CHO}$ cells (epithelial cell lines derived from the ovary of the Chinese hamster) (Cost et al. 2010; Santiago et al. 2008), plant tobacco (Cai et al. 2009), zebrafish (Doyon et al. 2008; Meng et al. 2008), rat (Geurts et al. 2009), and mouse ES cells (Goldberg et al. 2010).

ZFN technology was first applied in mice by two groups in 2010: (1) Meyer et al. (2010) described how ZFN can improve HDR efficiency of the targeting vector into target site fertilized mouse embryos; and (2) Carbery et al. (2010) reported that gene disruption using ZFN can be achieved through NHEJ event. Through these studies, it became obvious that (1) ZFN can be applied and replace mouse ES cells to generate genetically-engineered mice and (2) rather, engineered endonucleases must be advantageous over the classical gene targeting in moue ES cells as genome editing can be achieved by the single step injection of ZFN in a strain (or genetic background)-independent manner.

In 2013, another FokI-based engineered endonuclease called TALEN was revealed to have specific gene targeting ability to produce knockout mice (Sung et al. 2013), and Wang et al. (2013) reported that CRISPR/Cas9 was also useful for genome editing in mice and that co-injection of multiple guide RNAs could induce multiple mutations in mouse genome, simultaneously. Moreover, it is recently revealed that $\mathrm{Cpf} 1$ can be a useful genome editing approach in mammals including mouse (Kim et al. 2016; Hur et al. 2016) and rat (data not yet published), but more researches into this next-generation engineered endonuclease are in progress to explore its application in a range of another mammals.

\section{Rat}

The rat is a more widely used model for studying human normal physiology or diseases and for testing drug efficacy or toxicity prior to clinical trials in humans (Jacob 1999; Jacob and Kwitek 2002; Aitman et al. 2008). As an animal 
model for human diseases, the rat model provides many advantages over mouse: (1) its larger size compared to mouse provides easier handling and surgery, a larger sample volume, and high-resolution imaging, (2) the rich behavioral profile in rat is superior to that of mouse, particularly for learning and memory (Whishaw 1995; Whishaw and Tomie 1996), addiction (Jupp et al. 2013), and juvenile play (Hamilton et al. 2014), which is advantageous in neuroscience research, and (3) most importantly, rat is more translational than mouse due to its physiological similarity to human (Aitman et al. 2016).

Before the emergence of ES cell-mediated gene targeting, mutant rat strains were generated by random mutagenesis using a chemical mutagen N-ethyl-N-nitrosourea (ENU) or by introducing a sleeping beauty transposon (Zan et al. 2003; Izsvak et al. 2010). As the mutant strains were identified by phenotype-driven screening, these strategies require large populations of rats and were costly and timeconsuming processes of high-throughput screening. For the gene targeting, several methodological attempts have been made to establish authentic rat ES cells, and a culture system optimized for maintaining rat ES cells was finally developed (Buehr et al. 2008; Li et al. 2008), leading to the production of p53 KO rats (Tong et al. 2010). However, as the rat ES cells seems to be less robust than mouse ES cell and now plenty of mutant mouse resources publicly available (e.g., International Mouse Phenotyping Consortium or IMPC), most of in vivo studies employing mutant animal models are adopting mouse models.

Considering the importance and the difficulties of ES cell-based genome editing, it is an inevitable consequence that the rat is the first mammal species applied for genome editing with ZFN (Geurts et al. 2009) and TALEN (Tesson et al. 2011). Pronuclear or intracytoplasmic microinjection of ZFN or TALEN-encoding DNA or mRNA into fertilized rat eggs results in targeted gene knockout with a high efficiency. The CRISPR/Cas9 system was also proved to be adaptable for rat genome editing, and in particular, the coinjection of two or more guide RNAs with Cas9 mRNA led to multiple disruptions simultaneously in the rat genome (Li et al. 2013a, b).

\section{Rabbit}

The rabbit has been used for a long time in experimental research such as the production of antibodies or recombinant proteins and various toxicological studies for nonclinical safety studies, and was in fact the first animal model used for human atherosclerosis more than a century ago. Rabbit models for human disease have been developed to study lipid metabolism, atherosclerosis, osteoarthritis (Fan and Watanabe 2003; Martinez-Calatrava et al. 2010), and eye researches (Kang and Grossniklaus 2011; Zernii et al. 2016).

Regardless of the demand for genetically-modified rabbit, naturally occurring or spontaneous mutant strains were only available (Bosze and Houdebine 2006). Since the first transgenic rabbit was produced through the pronuclear microinjection of a DNA construct (Hammer et al. 1985), some methodological improvements have been reported for rabbit transgenesis (Viglietta et al. 1997; Besenfelder et al. 1998); however, it is still characterized by too-low transgenic efficiency (Houdebine and Fan 2009; Bosze et al. 2016). As the lack of fully functional rabbit ES cells was not produced (Honda et al. 2013; Honsho et al. 2015) and somatic cell nuclear transfer (SCNT) technologies are not established in rabbits (Zakhartchenko et al. 2011), still the targeted genome editing was not possible before the application of engineered endonucleases.

Those hurdles are now solved in rabbit by applying engineered endonucleases such as ZFN, TALEN, and the CRISPR/Cas9. In particular, in the last 5 years, studies using CRISPR/Cas9 for genome editing in rabbit have exceeded those of ZFN or TALEN quantitatively in spite of the relatively short history of the CRISPR system: there are only two or three studies of genetically-modified rabbit with ZFN (Flisikowska et al. 2011; Yang et al. 2013; Ji et al. 2015) or TALEN (Song et al. 2013, 2016a). However, we found 15 papers in the Medline applying CRISPR/Cas9 for genome editing in rabbit, and this number is continually increasing (Yang et al. 2014; Yan et al. 2014; Honda et al. 2015; Song et al. 2016a, b; Yuan et al. 2016; Lv et al. 2016; Yang et al. 2016; Sui et al. 2016; Guo et al. 2016; Song et al. 2017b; Yuan et al. 2017; Song et al. 2017a; Liu et al. 2018) due to its simplicity in design, high mutation efficiency, and the ability to simultaneously edit the genome of multiple genes, which seems superior to ZFN or TALEN in rabbit.

\section{Dog}

Dogs are of great benefit in their service to humankind including companionship and working activities, and have been also used as models in biomedical research. The advantages of using dog as an animal model include its anatomy, physiology, genetics, behavior, and its relatively long lifespan and size, which more closely match humans than other species such as rodents (Chianese et al. 2011). Indeed, dogs have proven remarkable model systems to investigate various hereditary human diseases including leukocyte adhesion deficiency, Leber's congenital amaurosis, Duchenne muscular dystrophy, and hemophilia A and B (Bauer and Hickstein 2000; Acland et al. 2001; Kinali et al. 2009; Margaritis 2010) because they have been 
selectively bred, which has resulted in a range of spontaneous and complex phenotypic variations that are often accompanied by undesired pathological genetic variations that were not observed in other species (Nowend et al. 2011; Switonski 2014). Many hereditary diseases in dogs naturally occur in very similar clinical manners to analogous human diseases (Shearin and Ostrander 2010).

Regardless of the importance of dogs in biomedical research and increasing demand for their genetic modification, studies into the manipulation of the dog genome are extremely limited in number. As compared to other mammals, dogs have certain unique species-specific characteristics that can be obstacles for artificial reproduction; for example, difficulty in synchronizing the reproduction stage between donor zygotes and recipient female dogs (Holst and Phemister 1971; Farstad 2000; Jang et al. 2007). These limit the application of dogs, particularly in the field of genome editing.

Finally, Zou et al. modified the dog genome successfully in 2015 using the CRISPR/Cas9 system, where the asynchronous reproduction stage in the donor and recipient was overcome via auto-transplantation of guide RNA/Cas9 mixture-injected zygotes into the same female dog (Zou et al. 2015). Therefore, the CRISPR/Cas9 system may be the primary choice for the generation of future novel dog models for biomedical research.

\section{Pig}

Pigs are very similar to humans in terms of anatomy, genetics, and physiology: (1) In terms of anatomy, the similarities in the size and morphology of their internal organs to those of humans allows various surgical and nonsurgical procedures in clinical settings such as catheterization, heart surgery, valve manipulation, endoscopy, and broncho-alveolar lavages, and thus pigs are frequently used as the general surgical model for both training and research over the last 20 years (Swindle et al. 2012). (2) The pig is phylogenetically closer to primates than rodents and thus the size and composition of the porcine genome are much more similar to those of humans. In particular, some inbred porcine strains with defined genetic background have been established, which enables us to obtain reproducible results (Kobayashi et al. 2012; Zhao et al. 2009). (3) In terms of physiology, the immune system in pigs is similar to that of humans, and their organs generally have functional features in common with humans (Swindle et al. 2012). In these regards, pigs have been considered as one of the major mammals in translational research, and considering their frequent application in studying the human diseases including Huntington's disease (HD), Alzheimer's disease (AD), retinitis pigmentosa, cystic fibrosis, cancer, and diabetes, the preclinical toxicological and efficacy testing of pharmaceuticals, and the xenotransplantation of pig organs to human (Aigner et al. 2010; Whyte and Prather 2011; Meurens et al. 2012), genetically-engineered pigs will be of great use in bio-medical studies.

The first transgenic pig was established by the microinjection of DNA construct into zygotes in 1985, and then various methodological procedures have been developed for efficient transgenesis in pigs, including spermmediated gene transfer (SMGT) (Lavitrano et al. 1997), intracytoplasmic sperm injection (ICSI)-mediated gene transfer (Kurome et al. 2006), and strategies employing viral vectors (Cabot et al. 2001; Hofmann et al. 2003). Most importantly, the SCNT technique was historically the most important advance in porcine genome engineering (Polejaeva et al. 2000), but the procedure is massive and complex, and the efficiency is extremely low. Similar to other species, the lack of functional porcine ES cells impedes the generation of genetically-engineered pigs.

The first ZFN-mediated knockout pigs were successfully generated in 2011 (Whyte et al. 2011), after which several groups generated knockout pigs using TALEN (Carlson et al. 2012) and CRISPR/Cas9 (Hai et al. 2014). Currently, engineered endonuclease-based genome editing are actively used to develop genetically-modified pigs that recapitulate human diseases in pigs (Watanabe et al. 2013; Umeyama et al. 2016), donor pigs for xenotransplantation (Hauschild et al. 2011; Miyagawa et al. 2015), and organdeficient pigs for the production of humanized organs by blastocyst complementation (Nagashima and Matsunari 2016), and agricultural use (Rao et al. 2016; Whitworth et al. 2016).

\section{Non-human primate}

Non-human primates (NHPs) are the ultimate animal models (phylogenetically closest to humans) that have been used in the fields of studying psychiatric disorders (Bachevalier et al. 2001; Yang et al. 2008; Gilley et al. 2011), metabolic function (O'Sullivan et al. 2013), reproductive biology (Wolf 2009; Kundu et al. 2013), and immunology (Thomas et al. 1982; Gallo et al. 1989), as those conditions cannot always be recapitulated by the rodent model. In spite of the cognitive and psychological superiority of NHPs to the other species, there are some limitations in using NHPs as an animal model such as ethical concerns when using higher primates, supply limitations, and relative cost ineffectiveness compared to smaller mammals, which should be of concern in the development of genetically-modified NHPs (Chan 2013).

Along with the NHP-specific limitations above, former technologies established in other species such as rodents 
were inefficient for manipulating the genome in monkeys, leading to rather slow progress regarding the generation of transgenic NHPs. In 2014, rhesus and cynomolgus monkeys were the first to be genetically modified with CRISPR/Cas9 (Niu et al. 2014) and TALEN (Liu et al. 2014), followed by genetically edited NHPs using ZFN in 2016 (Sato et al. 2016), and several subsequent NHP models that used engineered endonucleases have been successfully developed, opening a new era of genetic engineering in NHPs.

\section{Strategies for precise laboratory animal model mimicking human diseases}

Till now, we mainly described the studies achieving in-del mutations with engineered endonucleases. However, precise genome editing harnessing the power of HDR must be the main goal regardless of the species. Using this mechanism, animal models mimicking disease-associated single nucleotide polymorphisms (SNPs) can be modeled in diverse animal species. Furthermore, considering the future use of engineered endonucleases as a drug for a gene therapy, sequence-humanized animal models will be produced and may be an essential system for preclinical studies evaluating drug safety and effectiveness. The specific knock-in (KI) strategy that uses CRISPR/Cas9 is based on the co-injection of CRISPR/Cas9 components with doublestranded DNA or single-stranded oligodeoxynucleotides (ssODN) templates, and ssODN-mediated $\mathrm{KI}$ in mammalian cells occurs through the HDR mechanism and is more efficient than using double-stranded donor plasmids (Radecke et al. 2010; Chen et al. 2011). The utilization of this platform enables the insertion, deletion, or replacement of genetic materials of interest into the genome (Ma et al. 2014; Shao et al. 2014). Several small molecules, such as RAD51-stimulatory compound 1 (RS-1) or Scr7, which enhance the HDR pathway or inhibit the NHEJ pathway, are known to increase the HDR efficiency when coupled with the CRISPR/Cas9 system in mammalian cells (Chu et al. 2015; Maruyama et al. 2015), mice (Maruyama et al. 2015), and rabbits (Song et al. 2016a), but difficulties remain with the KI strategy in cell lines and animals due to the low HDR frequency, which remains to be optimized to attain higher efficiency. In alignment with efforts for higher efficiency in modeling SNPs, it is recently revealed that RNA-guided deaminases including adenine base editors (ABEs) and cytosine base editors (CBEs), composed of an engineered deaminase and a catalytically impaired Cas9 variant, can introduce a single-base-pair conversion A:T to $\mathrm{G}: \mathrm{C}$ or vice versa at a target site without DSBs (Gaudelli et al. 2017; Komor et al. 2016), enabling efficient programmable base editing. Among these newly designed chimeric nucleases, base editor 3 (BE3), one of CBEs, was successfully adopted in generating mice with point mutation at the target site with high efficiency (Kim et al. 2017), but its application in another laboratory animals remains to be further elucidated.

\section{Conclusion and perspective}

The initial uses of engineered endonucleases have demonstrated their possible applications for establishing novel model organisms and genome editing systems are constantly evolving. Particularly, through genome editing using these engineered endonucleases, there are tremendous efforts to recapitulate the human disease-associated mutations in various mammalian species. Precisely-designed animals to mimic the patient-derived mutations can be more translational and thus narrow down the gaps currently present between preclinical and clinical studies.

However, the production of mutant animals with precisely-defined genetic alterations is still challenging. To enhance the efficiency of HDR in diverse mammalian species, we need to study the specific physiology involved in the regulation of HDR in fertilized eggs. There are many suggestions possibly beneficial to increase the genomeediting efficiency (e.g., suppressing NHEJ or enhancing HDR), but their exact underlying mechanisms and appropriate strategies of applications for various mammals remain to be elucidated. Furthermore, each model mammals show species-specific reproductive characteristics such as estrous cycle and gamete physiology, which may affect the HDR in fertilized eggs and thus should be taken into account for mammalian genome editing.

Taken together, the use of genetically-modified mammals generated with engineered endonucleases can provide both fundamental and advanced model system or platform to understand physiological and pathological phenomena and thus help us to develop new drugs and treatments for human diseases.

Acknowledgements This work was supported by National Research Foundation of Korea (NRF) Grants (2017M3A9C4065958: Y.H.S., 2017R1A2B4011456: I.-J.B).

\section{Compliance with ethical standards}

Conflicts of interest The authors declare no conflicts of interest.

Open Access This article is distributed under the terms of the Creative Commons Attribution 4.0 International License (http://crea tivecommons.org/licenses/by/4.0/), which permits unrestricted use, distribution, and reproduction in any medium, provided you give appropriate credit to the original author(s) and the source, provide a link to the Creative Commons license, and indicate if changes were made. 


\section{References}

Acland GM, Aguirre GD, Ray J, Zhang Q, Aleman TS, Cideciyan AV, Pearce-Kelling SE, Anand V, Zeng Y, Maguire AM, Jacobson SG, Hauswirth WW, Bennett J (2001) Gene therapy restores vision in a canine model of childhood blindness. Nat Genet 28:92-95

Aigner B, Renner S, Kessler B, Klymiuk N, Kurome M, Wunsch A, Wolf E (2010) Transgenic pigs as models for translational biomedical research. J Mol Med (Berl) 88:653-664

Aitman TJ, Critser JK, Cuppen E, Dominiczak A, Fernandez-Suarez XM, Flint J, Gauguier D, Geurts AM, Gould M, Harris PC, Holmdahl R, Hubner N, Izsvak Z, Jacob HJ, Kuramoto T, Kwitek AE, Marrone A, Mashimo T, Moreno C, Mullins J, Mullins L, Olsson T, Pravenec M, Riley L, Saar K, Serikawa T, Shull JD, Szpirer C, Twigger SN, Voigt B, Worley K (2008) Progress and prospects in rat genetics: a community view. Nat Genet 40:516-522

Aitman T, Dhillon P, Geurts AM (2016) A RATional choice for translational research? Dis Model Mech 9:1069-1072

Bachevalier J, Malkova L, Mishkin M (2001) Effects of selective neonatal temporal lobe lesions on socioemotional behavior in infant rhesus monkeys (Macaca mulatta). Behav Neurosci 115:545-559

Barrangou R, Fremaux C, Deveau H, Richards M, Boyaval P, Moineau S, Romero DA, Horvath P (2007) CRISPR provides acquired resistance against viruses in prokaryotes. Science 315:1709-1712

Bauer TR Jr, Hickstein DD (2000) Gene therapy for leukocyte adhesion deficiency. Curr Opin Mol Ther 2:383-388

Besenfelder U, Aigner B, Muller M, Gottfried B (1998) Generation and application of transgenic rabbits. In: Cid-Arregui A (eds) Microinjection and transgenesis: strategies and protocols. Springer, Berlin/Heidelberg

Bibikova M, Golic M, Golic KG, Carroll D (2002) Targeted chromosomal cleavage and mutagenesis in Drosophila using zinc-finger nucleases. Genetics 161:1169-1175

Bibikova M, Beumer K, Trautman JK, Carroll D (2003) Enhancing gene targeting with designed zinc finger nucleases. Science 300:764

Boguski MS (2002) Comparative genomics: the mouse that roared. Nature 420:515-516

Bonas U, Stall RE, Staskawicz B (1989) Genetic and structural characterization of the avirulence gene avrBs3 from Xanthomonas campestris pv. vesicatoria. Mol Gen Genet 218:127-136

Bosze Z, Houdebine LM (2006) Application of rabbits in biomedical research: a review. World Rabbit Sci 14:1-14

Bosze Z, Major P, Baczko I, Odening KE, Bodrogi L, Hiripi L, Varro A (2016) The potential impact of new generation transgenic methods on creating rabbit models of cardiac diseases. Prog Biophys Mol Biol 121:123-130

Buehr M, Meek S, Blair K, Yang J, Ure J, Silva J, McLay R, Hall J, Ying QL, Smith A (2008) Capture of authentic embryonic stem cells from rat blastocysts. Cell 135:1287-1298

Cabot RA, Kuhholzer B, Chan AW, Lai L, Park KW, Chong KY, Schatten G, Murphy CN, Abeydeera LR, Day BN, Prather RS (2001) Transgenic pigs produced using in vitro matured oocytes infected with a retroviral vector. Anim Biotechnol 12:205-214

Cade L, Reyon D, Hwang WY, Tsai SQ, Patel S, Khayter C, Joung JK, Sander JD, Peterson RT, Yeh JR (2012) Highly efficient generation of heritable zebrafish gene mutations using homoand heterodimeric TALENs. Nucleic Acids Res 40:8001-8010

Cai CQ, Doyon Y, Ainley WM, Miller JC, Dekelver RC, Moehle EA, Rock JM, Lee YL, Garrison R, Schulenberg L, Blue R, Worden
A, Baker L, Faraji F, Zhang L, Holmes MC, Rebar EJ, Collingwood TN, Rubin-Wilson B, Gregory PD, Urnov FD, Petolino JF (2009) Targeted transgene integration in plant cells using designed zinc finger nucleases. Plant Mol Biol 69:699-709

Capecchi MR (1989) The new mouse genetics: altering the genome by gene targeting. Trends Genet 5:70-76

Carbery ID, Ji D, Harrington A, Brown V, Weinstein EJ, Liaw L, Cui $\mathrm{X}$ (2010) Targeted genome modification in mice using zincfinger nucleases. Genetics 186:451-459

Carlson DF, Tan W, Lillico SG, Stverakova D, Proudfoot C, Christian M, Voytas DF, Long CR, Whitelaw CB, Fahrenkrug SC (2012) Efficient TALEN-mediated gene knockout in livestock. Proc Natl Acad Sci USA 109:17382-17387

Ceccaldi R, Rondinelli B, D’Andrea AD (2016) Repair pathway choices and consequences at the double-strand break. Trends Cell Biol 26:52-64

Chan AW (2013) Progress and prospects for genetic modification of nonhuman primate models in biomedical research. ILAR J 54:211-223

Chen F, Pruett-Miller SM, Huang Y, Gjoka M, Duda K, Taunton J, Collingwood TN, Frodin M, Davis GD (2011) High-frequency genome editing using ssDNA oligonucleotides with zinc-finger nucleases. Nat Methods 8:753-755

Chianese R, Chioccarelli T, Cacciola G, Ciaramella V, Fasano S, Pierantoni R, Meccariello R, Cobellis G (2011) The contribution of lower vertebrate animal models in human reproduction research. Gen Comp Endocrinol 171:17-27

Chu VT, Weber T, Wefers B, Wurst W, Sander S, Rajewsky K, Kuhn $R$ (2015) Increasing the efficiency of homology-directed repair for CRISPR-Cas9-induced precise gene editing in mammalian cells. Nat Biotechnol 33:543-548

Cong L, Ran FA, Cox D, Lin S, Barretto R, Habib N, Hsu PD, Wu X, Jiang W, Marraffini LA, Zhang F (2013) Multiplex genome engineering using CRISPR/Cas systems. Science 339:819-823

Cost GJ, Freyvert Y, Vafiadis A, Santiago Y, Miller JC, Rebar E, Collingwood TN, Snowden A, Gregory PD (2010) BAK and BAX deletion using zinc-finger nucleases yields apoptosisresistant CHO cells. Biotechnol Bioeng 105:330-340

Dow LE (2015) Modeling disease in vivo with CRISPR/Cas9. Trends Mol Med 21:609-621

Doyon Y, McCammon JM, Miller JC, Faraji F, Ngo C, Katibah GE, Amora R, Hocking TD, Zhang L, Rebar EJ, Gregory PD, Urnov FD, Amacher SL (2008) Heritable targeted gene disruption in zebrafish using designed zinc-finger nucleases. Nat Biotechnol 26:702-708

Eppig JT (2017) Mouse genome informatics (MGI) resource: genetic, genomic, and biological knowledgebase for the laboratory mouse. ILAR J 58:17-41

Fan J, Watanabe T (2003) Transgenic rabbits as therapeutic protein bioreactors and human disease models. Pharmacol Ther 99:261-282

Farstad W (2000) Assisted reproductive technology in canid species. Theriogenology 53:175-186

Flisikowska T, Thorey IS, Offner S, Ros F, Lifke V, Zeitler B, Rottmann O, Vincent A, Zhang L, Jenkins S, Niersbach H, Kind AJ, Gregory PD, Schnieke AE, Platzer J (2011) Efficient immunoglobulin gene disruption and targeted replacement in rabbit using zinc finger nucleases. PLoS ONE 6:e21045

Fu Y, Foden JA, Khayter C, Maeder ML, Reyon D, Joung JK, Sander JD (2013) High-frequency off-target mutagenesis induced by CRISPR-Cas nucleases in human cells. Nat Biotechnol $31: 822-826$

Gaj T, Gersbach CA, Barbas CF 3rd (2013) ZFN, TALEN, and CRISPR/Cas-based methods for genome engineering. Trends Biotechnol 31:397-405 
Gallo P, Cupic D, Bracco F, Krzalic L, Tavolato B, Battistin L (1989) Experimental allergic encephalomyelitis in the monkey: humoral immunity and blood-brain barrier function. Ital $\mathbf{J}$ Neurol Sci 10:561-565

Gaudelli NM, Komor AC, Rees HA, Packer MS, Badran AH, Bryson DI, Liu DR (2017) Programmable base editing of $A^{*} T$ to $G^{*} C$ in genomic DNA without DNA cleavage. Nature 551:464-471

Geurts AM, Cost GJ, Freyvert Y, Zeitler B, Miller JC, Choi VM, Jenkins SS, Wood A, Cui X, Meng X, Vincent A, Lam S, Michalkiewicz M, Schilling R, Foeckler J, Kalloway S, Weiler H, Menoret S, Anegon I, Davis GD, Zhang L, Rebar EJ, Gregory PD, Urnov FD, Jacob HJ, Buelow R (2009) Knockout rats via embryo microinjection of zinc-finger nucleases. Science 325:433

Gilley J, Adalbert R, Coleman MP (2011) Modelling early responses to neurodegenerative mutations in mice. Biochem Soc Trans 39:933-938

Goldberg AD, Banaszynski LA, Noh KM, Lewis PW, Elsaesser SJ, Stadler S, Dewell S, Law M, Guo X, Li X, Wen D, Chapgier A, DeKelver RC, Miller JC, Lee YL, Boydston EA, Holmes MC, Gregory PD, Greally JM, Rafii S, Yang C, Scambler PJ, Garrick D, Gibbons RJ, Higgs DR, Cristea IM, Urnov FD, Zheng D, Allis CD (2010) Distinct factors control histone variant H3.3 localization at specific genomic regions. Cell 140:678-691

Golding MC, Long CR, Carmell MA, Hannon GJ, Westhusin ME (2006) Suppression of prion protein in livestock by RNA interference. Proc Natl Acad Sci USA 103:5285-5290

Guilinger JP, Thompson DB, Liu DR (2014) Fusion of catalytically inactive Cas9 to FokI nuclease improves the specificity of genome modification. Nat Biotechnol 32:577-582

Guo R, Wan Y, Xu D, Cui L, Deng M, Zhang G, Jia R, Zhou W, Wang Z, Deng K, Huang M, Wang F, Zhang Y (2016) Generation and evaluation of myostatin knock-out rabbits and goats using CRISPR/Cas9 system. Sci Rep 6:29855

Hai T, Teng F, Guo R, Li W, Zhou Q (2014) One-step generation of knockout pigs by zygote injection of CRISPR/Cas system. Cell Res 24:372-375

Hamilton SM, Green JR, Veeraragavan S, Yuva L, McCoy A, Wu Y, Warren J, Little L, Ji D, Cui X, Weinstein E, Paylor R (2014) Fmr1 and Nlgn3 knockout rats: novel tools for investigating autism spectrum disorders. Behav Neurosci 128:103-109

Hammer RE, Pursel VG, Rexroad CE Jr, Wall RJ, Bolt DJ, Ebert KM, Palmiter RD, Brinster RL (1985) Production of transgenic rabbits, sheep and pigs by microinjection. Nature 315:680-683

Hauschild J, Petersen B, Santiago Y, Queisser AL, Carnwath JW, Lucas-Hahn A, Zhang L, Meng X, Gregory PD, Schwinzer R, Cost GJ, Niemann H (2011) Efficient generation of a biallelic knockout in pigs using zinc-finger nucleases. Proc Natl Acad Sci USA 108:12013-12017

Hockemeyer D, Soldner F, Beard C, Gao Q, Mitalipova M, DeKelver RC, Katibah GE, Amora R, Boydston EA, Zeitler B, Meng X, Miller JC, Zhang L, Rebar EJ, Gregory PD, Urnov FD, Jaenisch R (2009) Efficient targeting of expressed and silent genes in human ESCs and iPSCs using zinc-finger nucleases. Nat Biotechnol 27:851-857

Hockemeyer D, Wang H, Kiani S, Lai CS, Gao Q, Cassady JP, Cost GJ, Zhang L, Santiago Y, Miller JC, Zeitler B, Cherone JM, Meng X, Hinkley SJ, Rebar EJ, Gregory PD, Urnov FD, Jaenisch R (2011) Genetic engineering of human pluripotent cells using TALE nucleases. Nat Biotechnol 29:731-734

Hofmann A, Kessler B, Ewerling S, Weppert M, Vogg B, Ludwig H, Stojkovic M, Boelhauve M, Brem G, Wolf E, Pfeifer A (2003) Efficient transgenesis in farm animals by lentiviral vectors. EMBO Rep 4:1054-1060

Holst PA, Phemister RD (1971) The prenatal development of the dog: preimplantation events. Biol Reprod 5:194-206
Honda A, Hatori M, Hirose M, Honda C, Izu H, Inoue K, Hirasawa R, Matoba S, Togayachi S, Miyoshi H, Ogura A (2013) Naive-like conversion overcomes the limited differentiation capacity of induced pluripotent stem cells. J Biol Chem 288:26157-26166

Honda A, Hirose M, Sankai T, Yasmin L, Yuzawa K, Honsho K, Izu H, Iguchi A, Ikawa M, Ogura A (2015) Single-step generation of rabbits carrying a targeted allele of the tyrosinase gene using CRISPR/Cas9. Exp Anim 64:31-37

Honsho K, Hirose M, Hatori M, Yasmin L, Izu H, Matoba S, Togayachi S, Miyoshi H, Sankai T, Ogura A, Honda A (2015) Naive-like conversion enhances the difference in innate in vitro differentiation capacity between rabbit ES cells and iPS cells. J Reprod Dev 61:13-19

Houdebine LM, Fan J (2009) Rabbit biotechnology: rabbit genomics, transgenesis, cloning and models. Springer Science \& Business Media, Heildelberg/Berlin/New York

Hsu PD, Scott DA, Weinstein JA, Ran FA, Konermann S, Agarwala V, Li Y, Fine EJ, Wu X, Shalem O, Cradick TJ, Marraffini LA, Bao G, Zhang F (2013) DNA targeting specificity of RNAguided Cas9 nucleases. Nat Biotechnol 31:827-832

Huang P, Xiao A, Zhou M, Zhu Z, Lin S, Zhang B (2011) Heritable gene targeting in zebrafish using customized TALENs. Nat Biotechnol 29:699-700

Hur JK, Kim K, Been KW, Baek G, Ye S, Hur JW, Ryu SM, Lee YS, Kim JS (2016) Targeted mutagenesis in mice by electroporation of Cpf1 ribonucleoproteins. Nat Biotechnol 34:807-808

Izsvak Z, Frohlich J, Grabundzija I, Shirley JR, Powell HM, Chapman KM, Ivics Z, Hamra FK (2010) Generating knockout rats by transposon mutagenesis in spermatogonial stem cells. Nat Methods 7:443-445

Jacob HJ (1999) Functional genomics and rat models. Genome Res 9:1013-1016

Jacob HJ, Kwitek AE (2002) Rat genetics: attaching physiology and pharmacology to the genome. Nat Rev Genet 3:33-42

Jang G, Kim MK, Oh HJ, Hossein MS, Fibrianto YH, Hong SG, Park JE, Kim JJ, Kim HJ, Kang SK, Kim DY, Lee BC (2007) Birth of viable female dogs produced by somatic cell nuclear transfer. Theriogenology 67:941-947

Ji D, Zhao G, Songstad A, Cui X, Weinstein EJ (2015) Efficient creation of an APOE knockout rabbit. Transgenic Res 24:227-235

Jinek M, Chylinski K, Fonfara I, Hauer M, Doudna JA, Charpentier E (2012) A programmable dual-RNA-guided DNA endonuclease in adaptive bacterial immunity. Science 337:816-821

Jupp B, Caprioli D, Dalley JW (2013) Highly impulsive rats: modelling an endophenotype to determine the neurobiological, genetic and environmental mechanisms of addiction. Dis Model Mech 6:302-311

Kang SJ, Grossniklaus HE (2011) Rabbit model of retinoblastoma. J Biomed Biotechnol 2011:394730

Kay S, Hahn S, Marois E, Hause G, Bonas U (2007) A bacterial effector acts as a plant transcription factor and induces a cell size regulator. Science 318:648-651

Kim Y, Cheong SA, Lee JG, Lee SW, Lee MS, Baek IJ, Sung YH (2016) Generation of knockout mice by Cpf1-mediated gene targeting. Nat Biotechnol 34:808-810

Kim K, Ryu SM, Kim ST, Baek G, Kim D, Lim K, Chung E, Kim S, Kim JS (2017) Highly efficient RNA-guided base editing in mouse embryos. Nat Biotechnol 35:435-437

Kinali M, Arechavala-Gomeza V, Feng L, Cirak S, Hunt D, Adkin C, Guglieri M, Ashton E, Abbs S, Nihoyannopoulos P, Garralda ME, Rutherford M, McCulley C, Popplewell L, Graham IR, Dickson G, Wood MJ, Wells DJ, Wilton SD, Kole R, Straub V, Bushby K, Sewry C, Morgan JE, Muntoni F (2009) Local restoration of dystrophin expression with the morpholino oligomer AVI-4658 in Duchenne muscular dystrophy: a single- 
blind, placebo-controlled, dose-escalation, proof-of-concept study. Lancet Neurol 8:918-928

Kobayashi E, Hishikawa S, Teratani T, Lefor AT (2012) The pig as a model for translational research: overview of porcine animal models at Jichi Medical University. Transplant Res 1:8

Komor AC, Kim YB, Packer MS, Zuris JA, Liu DR (2016) Programmable editing of a target base in genomic DNA without double-stranded DNA cleavage. Nature 533:420-424

Kundu MC, May MC, Chosich J, Bradford AP, Lasley B, Gee N, Santoro N, Appt SE, Polotsky AJ (2013) Assessment of luteal function in the vervet monkey as a means to develop a model for obesity-related reproductive phenotype. Syst Biol Reprod Med 59:74-81

Kurome M, Ueda H, Tomii R, Naruse K, Nagashima H (2006) Production of transgenic-clone pigs by the combination of ICSImediated gene transfer with somatic cell nuclear transfer. Transgenic Res 15:229-240

Lavitrano M, Forni M, Varzi V, Pucci L, Bacci ML, Di Stefano C, Fioretti D, Zoraqi G, Moioli B, Rossi M, Lazzereschi D, Stoppacciaro A, Seren E, Alfani D, Cortesini R, Frati L (1997) Sperm-mediated gene transfer: production of pigs transgenic for a human regulator of complement activation. Transpl Proc 29:3508-3509

Li P, Tong C, Mehrian-Shai R, Jia L, Wu N, Yan Y, Maxson RE, Schulze EN, Song H, Hsieh CL, Pera MF, Ying QL (2008) Germline competent embryonic stem cells derived from rat blastocysts. Cell 135:1299-1310

Li D, Qiu Z, Shao Y, Chen Y, Guan Y, Liu M, Li Y, Gao N, Wang L, Lu X, Zhao Y, Liu M (2013a) Heritable gene targeting in the mouse and rat using a CRISPR-Cas system. Nat Biotechnol 31:681-683

Li W, Teng F, Li T, Zhou Q (2013b) Simultaneous generation and germline transmission of multiple gene mutations in rat using CRISPR-Cas systems. Nat Biotechnol 31:684-686

Li G, Zhang X, Zhong C, Mo J, Quan R, Yang J, Liu D, Li Z, Yang H, Wu Z (2017) Small molecules enhance CRISPR/Cas9-mediated homology-directed genome editing in primary cells. Sci Rep 7:8943

Liu H, Chen Y, Niu Y, Zhang K, Kang Y, Ge W, Liu X, Zhao E, Wang C, Lin S, Jing B, Si C, Lin Q, Chen X, Lin H, Pu X, Wang Y, Qin B, Wang F, Wang H, Si W, Zhou J, Tan T, Li T, Ji S, Xue Z, Luo Y, Cheng L, Zhou Q, Li S, Sun YE, Ji W (2014) TALENmediated gene mutagenesis in rhesus and cynomolgus monkeys. Cell Stem Cell 14:323-328

Liu H, Sui T, Liu D, Liu T, Chen M, Deng J, Xu Y, Li Z (2018) Multiple homologous genes knockout (KO) by CRISPR/Cas9 system in rabbit. Gene 647:261-267

Lombardo A, Genovese P, Beausejour CM, Colleoni S, Lee YL, Kim KA, Ando D, Urnov FD, Galli C, Gregory PD, Holmes MC, Naldini L (2007) Gene editing in human stem cells using zinc finger nucleases and integrase-defective lentiviral vector delivery. Nat Biotechnol 25:1298-1306

Lv Q, Yuan L, Deng J, Chen M, Wang Y, Zeng J, Li Z, Lai L (2016) Efficient generation of myostatin gene mutated rabbit by CRISPR/Cas9. Sci Rep 6:25029

Ma Y, Ma J, Zhang X, Chen W, Yu L, Lu Y, Bai L, Shen B, Huang X, Zhang L (2014) Generation of eGFP and Cre knockin rats by CRISPR/Cas9. FEBS J 281:3779-3790

Makarova KS, Haft DH, Barrangou R, Brouns SJ, Charpentier E, Horvath P, Moineau S, Mojica FJ, Wolf YI, Yakunin AF, van der Oost J, Koonin EV (2011) Evolution and classification of the CRISPR-Cas systems. Nat Rev Microbiol 9:467-477

Makarova KS, Wolf YI, Alkhnbashi OS, Costa F, Shah SA, Saunders SJ, Barrangou R, Brouns SJ, Charpentier E, Haft DH, Horvath P, Moineau S, Mojica FJ, Terns RM, Terns MP, White MF, Yakunin AF, Garrett RA, van der Oost J, Backofen R, Koonin
EV (2015) An updated evolutionary classification of CRISPRCas systems. Nat Rev Microbiol 13:722-736

Mali P, Aach J, Stranges PB, Esvelt KM, Moosburner M, Kosuri S, Yang L, Church GM (2013a) CAS9 transcriptional activators for target specificity screening and paired nickases for cooperative genome engineering. Nat Biotechnol 31:833-838

Mali P, Yang L, Esvelt KM, Aach J, Guell M, DiCarlo JE, Norville JE, Church GM (2013b) RNA-guided human genome engineering via Cas9. Science 339:823-826

Margaritis P (2010) Long-term expression of canine FVIIa in hemophilic dogs. Thromb Res 125(Suppl 1):S60-S62

Martinez-Calatrava MJ, Largo R, Herrero-Beaumont G (2010) Improvement of experimental accelerated atherosclerosis by chondroitin sulphate. Osteoarthr Cartil 18(Suppl 1):S12-S16

Maruyama T, Dougan SK, Truttmann MC, Bilate AM, Ingram JR, Ploegh HL (2015) Increasing the efficiency of precise genome editing with CRISPR-Cas9 by inhibition of nonhomologous end joining. Nat Biotechnol 33:538-542

Mashimo T, Takizawa A, Voigt B, Yoshimi K, Hiai H, Kuramoto T, Serikawa T (2010) Generation of knockout rats with X-linked severe combined immunodeficiency (X-SCID) using zinc-finger nucleases. PLoS ONE 5:e8870

Meng X, Noyes MB, Zhu LJ, Lawson ND, Wolfe SA (2008) Targeted gene inactivation in zebrafish using engineered zinc-finger nucleases. Nat Biotechnol 26:695-701

Method of the year 2011 (2012) Nat Methods 9:1

Meurens F, Summerfield A, Nauwynck H, Saif L, Gerdts V (2012) The pig: a model for human infectious diseases. Trends Microbiol 20:50-57

Meyer M, de Angelis MH, Wurst W, Kuhn R (2010) Gene targeting by homologous recombination in mouse zygotes mediated by zinc-finger nucleases. Proc Natl Acad Sci USA 107:15022-15026

Miller J, McLachlan AD, Klug A (1985) Repetitive zinc-binding domains in the protein transcription factor IIIA from Xenopus oocytes. EMBO J 4:1609-1614

Miller JC, Holmes MC, Wang J, Guschin DY, Lee YL, Rupniewski I, Beausejour CM, Waite AJ, Wang NS, Kim KA, Gregory PD, Pabo CO, Rebar EJ (2007) An improved zinc-finger nuclease architecture for highly specific genome editing. Nat Biotechnol 25:778-785

Miller JC, Tan S, Qiao G, Barlow KA, Wang J, Xia DF, Meng X, Paschon DE, Leung E, Hinkley SJ, Dulay GP, Hua KL, Ankoudinova I, Cost GJ, Urnov FD, Zhang HS, Holmes MC, Zhang L, Gregory PD, Rebar EJ (2011) A TALE nuclease architecture for efficient genome editing. Nat Biotechnol 29:143-148

Miyagawa S, Matsunari H, Watanabe M, Nakano K, Umeyama K, Sakai R, Takayanagi S, Takeishi T, Fukuda T, Yashima S, Maeda A, Eguchi H, Okuyama H, Nagaya M, Nagashima $H$ (2015) Generation of alpha1,3-galactosyltransferase and cytidine monophospho- $N$-acetylneuraminic acid hydroxylase gene double-knockout pigs. J Reprod Dev 61:449-457

Moscou MJ, Bogdanove AJ (2009) A simple cipher governs DNA recognition by TAL effectors. Science 326:1501

Nagashima H, Matsunari H (2016) Growing human organs in pigs-a dream or reality? Theriogenology 86:422-426

Niu Y, Shen B, Cui Y, Chen Y, Wang J, Wang L, Kang Y, Zhao X, Si W, Li W, Xiang AP, Zhou J, Guo X, Bi Y, Si C, Hu B, Dong G, Wang H, Zhou Z, Li T, Tan T, Pu X, Wang F, Ji S, Zhou Q, Huang X, Ji W, Sha J (2014) Generation of gene-modified cynomolgus monkey via Cas9/RNA-mediated gene targeting in one-cell embryos. Cell 156:836-843

Nowend KL, Starr-Moss AN, Murphy KE (2011) The function of dog models in developing gene therapy strategies for human health. Mamm Genome 22:476-485 
O'Sullivan A, He X, McNiven EM, Hinde K, Haggarty NW, Lonnerdal B, Slupsky CM (2013) Metabolomic phenotyping validates the infant rhesus monkey as a model of human infant metabolism. J Pediatr Gastroenterol Nutr 56:355-363

Paigen K (1995) A miracle enough: the power of mice. Nat Med $1: 215-220$

Pattanayak V, Lin S, Guilinger JP, Ma E, Doudna JA, Liu DR (2013) High-throughput profiling of off-target DNA cleavage reveals RNA-programmed Cas9 nuclease specificity. Nat Biotechnol 31:839-843

Perez EE, Wang J, Miller JC, Jouvenot Y, Kim KA, Liu O, Wang N, Lee G, Bartsevich VV, Lee YL, Guschin DY, Rupniewski I, Waite AJ, Carpenito C, Carroll RG, Orange JS, Urnov FD, Rebar EJ, Ando D, Gregory PD, Riley JL, Holmes MC, June CH (2008) Establishment of HIV-1 resistance in CD4+ T cells by genome editing using zinc-finger nucleases. Nat Biotechnol 26:808-816

Polejaeva IA, Chen SH, Vaught TD, Page RL, Mullins J, Ball S, Dai Y, Boone J, Walker S, Ayares DL, Colman A, Campbell KH (2000) Cloned pigs produced by nuclear transfer from adult somatic cells. Nature 407:86-90

Radecke S, Radecke F, Cathomen T, Schwarz K (2010) Zinc-finger nuclease-induced gene repair with oligodeoxynucleotides: wanted and unwanted target locus modifications. Mol Ther 18:743-753

Ramalingam S, Kandavelou K, Rajenderan R, Chandrasegaran S (2011) Creating designed zinc-finger nucleases with minimal cytotoxicity. J Mol Biol 405:630-641

Ran FA, Hsu PD, Lin CY, Gootenberg JS, Konermann S, Trevino AE, Scott DA, Inoue A, Matoba S, Zhang Y, Zhang F (2013) Double nicking by RNA-guided CRISPR Cas9 for enhanced genome editing specificity. Cell 154:1380-1389

Rao S, Fujimura T, Matsunari H, Sakuma T, Nakano K, Watanabe M, Asano Y, Kitagawa E, Yamamoto T, Nagashima H (2016) Efficient modification of the myostatin gene in porcine somatic cells and generation of knockout piglets. Mol Reprod Dev 83:61-70

Romer P, Hahn S, Jordan T, Strauss T, Bonas U, Lahaye T (2007) Plant pathogen recognition mediated by promoter activation of the pepper Bs3 resistance gene. Science 318:645-648

Sander JD, Joung JK (2014) CRISPR-Cas systems for editing, regulating and targeting genomes. Nat Biotechnol 32:347-355

Santiago Y, Chan E, Liu PQ, Orlando S, Zhang L, Urnov FD, Holmes MC, Guschin D, Waite A, Miller JC, Rebar EJ, Gregory PD, Klug A, Collingwood TN (2008) Targeted gene knockout in mammalian cells by using engineered zinc-finger nucleases. Proc Natl Acad Sci USA 105:5809-5814

Sato K, Oiwa R, Kumita W, Henry R, Sakuma T, Ito R, Nozu R, Inoue T, Katano I, Sato K, Okahara N, Okahara J, Shimizu Y, Yamamoto M, Hanazawa K, Kawakami T, Kametani Y, Suzuki R, Takahashi T, Weinstein EJ, Yamamoto T, Sakakibara Y, Habu S, Hata J, Okano H, Sasaki E (2016) Generation of a nonhuman primate model of severe combined immunodeficiency using highly efficient genome editing. Cell Stem Cell 19:127-138

Schunder E, Rydzewski K, Grunow R, Heuner K (2013) First indication for a functional CRISPR/Cas system in Francisella tularensis. Int J Med Microbiol 303:51-60

Shao Y, Guan Y, Wang L, Qiu Z, Liu M, Chen Y, Wu L, Li Y, Ma X, Liu M, Li D (2014) CRISPR/Cas-mediated genome editing in the rat via direct injection of one-cell embryos. Nat Protoc 9:2493-2512

Shao M, Xu TR, Chen CS (2016) The big bang of genome editing technology: development and application of the CRISPR/Cas9 system in disease animal models. Dongwuxue Yanjiu 37:191-204
Shearin AL, Ostrander EA (2010) Leading the way: canine models of genomics and disease. Dis Model Mech 3:27-34

Song J, Zhong J, Guo X, Chen Y, Zou Q, Huang J, Li X, Zhang Q, Jiang Z, Tang C, Yang H, Liu T, Li P, Pei D, Lai L (2013) Generation of RAG 1- and 2-deficient rabbits by embryo microinjection of TALENs. Cell Res 23:1059-1062

Song J, Yang D, Xu J, Zhu T, Chen YE, Zhang J (2016a) RS-1 enhances CRISPR/Cas9- and TALEN-mediated knock-in efficiency. Nat Commun 7:10548

Song Y, Yuan L, Wang Y, Chen M, Deng J, Lv Q, Sui T, Li Z, Lai L (2016b) Efficient dual sgRNA-directed large gene deletion in rabbit with CRISPR/Cas9 system. Cell Mol Life Sci 73:2959-2968

Song J, Yang D, Ruan J, Zhang J, Chen YE, Xu J (2017a) Production of immunodeficient rabbits by multiplex embryo transfer and multiplex gene targeting. Sci Rep 7:12202

Song Y, Liu T, Wang Y, Deng J, Chen M, Yuan L, Lu Y, Xu Y, Yao $\mathrm{H}$, Li Z, Lai L (2017b) Mutation of the Sp1 binding site in the $5^{\prime}$ flanking region of SRY causes sex reversal in rabbits. Oncotarget 8:38176-38183

Sui T, Yuan L, Liu H, Chen M, Deng J, Wang Y, Li Z, Lai L (2016) CRISPR/Cas9-mediated mutation of PHEX in rabbit recapitulates human X-linked hypophosphatemia (XLH). Hum Mol Genet 25:2661-2671

Sung YH, Baek IJ, Kim DH, Jeon J, Lee J, Lee K, Jeong D, Kim JS, Lee HW (2013) Knockout mice created by TALEN-mediated gene targeting. Nat Biotechnol 31:23-24

Swindle MM, Makin A, Herron AJ, Clubb FJ Jr, Frazier KS (2012) Swine as models in biomedical research and toxicology testing. Vet Pathol 49:344-356

Switonski M (2014) Dog as a model in studies on human hereditary diseases and their gene therapy. Reprod Biol 14:44-50

Szczepek M, Brondani V, Buchel J, Serrano L, Segal DJ, Cathomen T (2007) Structure-based redesign of the dimerization interface reduces the toxicity of zinc-finger nucleases. Nat Biotechnol 25:786-793

Tesson L, Usal C, Menoret S, Leung E, Niles BJ, Remy S, Santiago Y, Vincent AI, Meng X, Zhang L, Gregory PD, Anegon I, Cost GJ (2011) Knockout rats generated by embryo microinjection of TALENs. Nat Biotechnol 29:695-696

Thomas J, Carver M, Haisch C, Thomas F, Welch J, Carchman R (1982) Differential effects of intravenous anaesthetic agents on cell-mediated immunity in the Rhesus monkey. Clin Exp Immunol 47:457-466

Tong C, Li P, Wu NL, Yan Y, Ying QL (2010) Production of p53 gene knockout rats by homologous recombination in embryonic stem cells. Nature 467:211-213

Tsai SQ, Wyvekens N, Khayter C, Foden JA, Thapar V, Reyon D, Goodwin MJ, Aryee MJ, Joung JK (2014) Dimeric CRISPR RNA-guided FokI nucleases for highly specific genome editing. Nat Biotechnol 32:569-576

Umeyama K, Watanabe K, Watanabe M, Horiuchi K, Nakano K, Kitashiro M, Matsunari H, Kimura T, Arima Y, Sampetrean O, Nagaya M, Saito M, Saya H, Kosaki K, Nagashima H, Matsumoto M (2016) Generation of heterozygous fibrillin-1 mutant cloned pigs from genome-edited foetal fibroblasts. Sci Rep 6:24413

Urnov FD, Miller JC, Lee YL, Beausejour CM, Rock JM, Augustus S, Jamieson AC, Porteus MH, Gregory PD, Holmes MC (2005) Highly efficient endogenous human gene correction using designed zinc-finger nucleases. Nature 435:646-651

Urnov FD, Rebar EJ, Holmes MC, Zhang HS, Gregory PD (2010) Genome editing with engineered zinc finger nucleases. Nat Rev Genet 11:636-646

Vanamee ES, Santagata S, Aggarwal AK (2001) FokI requires two specific DNA sites for cleavage. J Mol Biol 309:69-78 
Vestergaard G, Garrett RA, Shah SA (2014) CRISPR adaptive immune systems of Archaea. RNA Biol 11:156-167

Viglietta C, Massoud M, Houdebine LM (1997) The generation of transgenic rabbits. In: Houdebine LM (ed) Transgenic animals: generation and use. Harwood Academic Publishers, Amsterdam

von Horsten S, Schmitt I, Nguyen HP, Holzmann C, Schmidt T, Walther T, Bader M, Pabst R, Kobbe P, Krotova J, Stiller D, Kask A, Vaarmann A, Rathke-Hartlieb S, Schulz JB, Grasshoff U, Bauer I, Vieira-Saecker AM, Paul M, Jones L, Lindenberg KS, Landwehrmeyer B, Bauer A, Li XJ, Riess O (2003) Transgenic rat model of Huntington's disease. Hum Mol Genet 12:617-624

Wang F, Qi LS (2016) Applications of CRISPR genome engineering in cell biology. Trends Cell Biol 26:875-888

Wang H, Yang H, Shivalila CS, Dawlaty MM, Cheng AW, Zhang F, Jaenisch R (2013) One-step generation of mice carrying mutations in multiple genes by CRISPR/Cas-mediated genome engineering. Cell 153:910-918

Watanabe M, Nakano K, Matsunari H, Matsuda T, Maehara M, Kanai T, Kobayashi M, Matsumura Y, Sakai R, Kuramoto M, Hayashida G, Asano Y, Takayanagi S, Arai Y, Umeyama K, Nagaya M, Hanazono Y, Nagashima H (2013) Generation of interleukin-2 receptor gamma gene knockout pigs from somatic cells genetically modified by zinc finger nuclease-encoding mRNA. PLoS ONE 8:e76478

Whishaw IQ (1995) A comparison of rats and mice in a swimming pool place task and matching to place task: some surprising differences. Physiol Behav 58:687-693

Whishaw IQ, Tomie J (1996) Of mice and mazes: similarities between mice and rats on dry land but not water mazes. Physiol Behav 60:1191-1197

Whitworth KM, Rowland RR, Ewen CL, Trible BR, Kerrigan MA, Cino-Ozuna AG, Samuel MS, Lightner JE, McLaren DG, Mileham AJ, Wells KD, Prather RS (2016) Gene-edited pigs are protected from porcine reproductive and respiratory syndrome virus. Nat Biotechnol 34:20-22

Whyte JJ, Prather RS (2011) Genetic modifications of pigs for medicine and agriculture. Mol Reprod Dev 78:879-891

Whyte JJ, Zhao J, Wells KD, Samuel MS, Whitworth KM, Walters EM, Laughlin MH, Prather RS (2011) Gene targeting with zinc finger nucleases to produce cloned eGFP knockout pigs. Mol Reprod Dev 78:2

Wolf DP (2009) Artificial insemination and the assisted reproductive technologies in non-human primates. Theriogenology 71:123-129

Wolfe SA, Nekludova L, Pabo CO (2000) DNA recognition by Cys2His2 zinc finger proteins. Annu Rev Biophys Biomol Struct 29:183-212

Yan Q, Zhang Q, Yang H, Zou Q, Tang C, Fan N, Lai L (2014) Generation of multi-gene knockout rabbits using the Cas9/gRNA system. Cell Regen (Lond) 3:12

Yang SH, Cheng PH, Banta H, Piotrowska-Nitsche K, Yang JJ, Cheng EC, Snyder B, Larkin K, Liu J, Orkin J, Fang ZH, Smith
Y, Bachevalier J, Zola SM, Li SH, Li XJ, Chan AW (2008) Towards a transgenic model of Huntington's disease in a nonhuman primate. Nature 453:921-924

Yang D, Zhang J, Xu J, Zhu T, Fan Y, Fan J, Chen YE (2013) Production of apolipoprotein C-III knockout rabbits using zinc finger nucleases. J Vis Exp. https://doi.org/10.3791/50957

Yang D, Xu J, Zhu T, Fan J, Lai L, Zhang J, Chen YE (2014) Effective gene targeting in rabbits using RNA-guided Cas9 nucleases. J Mol Cell Biol 6:97-99

Yang D, Song J, Zhang J, Xu J, Zhu T, Wang Z, Lai L, Chen YE (2016) Identification and characterization of rabbit ROSA26 for gene knock-in and stable reporter gene expression. Sci Rep 6:25161

Yuan L, Sui T, Chen M, Deng J, Huang Y, Zeng J, Lv Q, Song Y, Li Z, Lai L (2016) CRISPR/Cas9-mediated GJA8 knockout in rabbits recapitulates human congenital cataracts. Sci Rep 6:22024

Yuan L, Yao H, Xu Y, Chen M, Deng J, Song Y, Sui T, Wang Y, Huang Y, Li Z, Lai L (2017) CRISPR/Cas9-mediated mutation of alphaA-crystallin gene induces congenital cataracts in rabbits. Invest Ophthalmol Vis Sci 58:BIO34-BIO41

Zakhartchenko V, Flisikowska T, Li S, Richter T, Wieland H, Durkovic M, Rottmann O, Kessler B, Gungor T, Brem G, Kind A, Wolf E, Schnieke A (2011) Cell-mediated transgenesis in rabbits: chimeric and nuclear transfer animals. Biol Reprod 84:229-237

Zan Y, Haag JD, Chen KS, Shepel LA, Wigington D, Wang YR, Hu R, Lopez-Guajardo CC, Brose HL, Porter KI, Leonard RA, Hitt AA, Schommer SL, Elegbede AF, Gould MN (2003) Production of knockout rats using ENU mutagenesis and a yeast-based screening assay. Nat Biotechnol 21:645-651

Zernii EY, Baksheeva VE, Iomdina EN, Averina OA, Permyakov SE, Philippov PP, Zamyatnin AA, Senin II (2016) Rabbit models of ocular diseases: new relevance for classical approaches. CNS Neurol Disord Drug Targets 15:267-291

Zetsche B, Gootenberg JS, Abudayyeh OO, Slaymaker IM, Makarova KS, Essletzbichler P, Volz SE, Joung J, van der Oost J, Regev A, Koonin EV, Zhang F (2015) Cpf1 is a single RNA-guided endonuclease of a class 2 CRISPR-Cas system. Cell 163:759-771

Zhao J, Ross JW, Hao Y, Spate LD, Walters EM, Samuel MS, Rieke A, Murphy CN, Prather RS (2009) Significant improvement in cloning efficiency of an inbred miniature pig by histone deacetylase inhibitor treatment after somatic cell nuclear transfer. Biol Reprod 81:525-530

Zou Q, Wang X, Liu Y, Ouyang Z, Long H, Wei S, Xin J, Zhao B, Lai S, Shen J, Ni Q, Yang H, Zhong H, Li L, Hu M, Zhang Q, Zhou Z, He J, Yan Q, Fan N, Zhao Y, Liu Z, Guo L, Huang J, Zhang G, Ying J, Lai L, Gao X (2015) Generation of gene-target dogs using CRISPR/Cas9 system. J Mol Cell Biol 7:580-583

Zschemisch NH, Glage S, Wedekind D, Weinstein EJ, Cui X, Dorsch M, Hedrich HJ (2012) Zinc-finger nuclease mediated disruption of Rag1 in the LEW/Ztm rat. BMC Immunol 13:60 